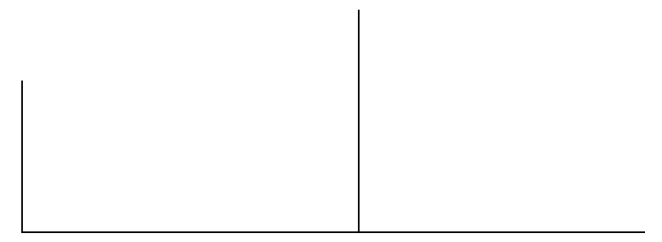

O mito de Ulisses. Estresse, câncer e imunologia

Fátima Deitos

Sta. Maria, RS. Edit. Kasa do Zé

1997

\title{
O mito de Ulisses
}

\section{Maurício Silveira Garrote}

O livro da Prof ${ }^{a}$ Fátima Deitos organiza e relata, de maneira clara, os achados biológicos mais recentes que dão materialidade às interações entre o mundo mental, o aparelho imunológico e o aparecimento e evolução das doenças neoplásicas.

Tudo isso numa primeira leitura. Mas uma leitura mais atenta nos leva a uma pergunta da maior importância no pensamento psicossomático contemporâneo. A pergunta de se os achados biológicos, como, por exemplo, da efetividade variável das células "natural killer" nos diferentes momentos da existência do indivíduo, não nos falam da materialidade e biologicidade do mundo mental, e não mais de sua interface com o mundo do corpo.

A antropóloga e médica Joan Halifax, em seu livro Shamanic voices, compila relatos de xamãs de várias procedências geoculturais, em suas próprias palavras. Observamos nesses relatos que a imagemconceito de “caminho da doença” é um patrimônio comum nessas tradições de cura. Quando o xamã passa por seu transe iniciático, visita junto com seu espírito protetor um lugar onde lhe são mostrados os caminhos da doença: onde os acontecimentos da doença são transformados em imagens de um percurso 
material, com lugares de difícil acesso, travessias perigosas, espíritos animais que podem ajudar ou atrapalhar em cada etapa em direção à cura.

Lévi-Strauss mostra, em Antropologia estrutural, como a narrativa do xamã junto ao doente dá sentido às sensações e sintomas vividos arbitrariamente até então, e transformando o sofrimento no tempo numa trajetória no espaço mental do paciente opera uma justaposição de partes do corpo doente com elementos míticos da mesma narrativa. Elementos com os quais xamã e paciente podem negociar, e que podem entrar na corporalidade mesma da cura. Esse achado monumental, a eficácia simbólica, é iluminado nas páginas do livro da Prof ${ }^{a}$ Deitos, onde somos apresentados a novas entidades que serão incorporadas em nosso imaginário médico-terapêutico como personagens míticos da narrativa singular de cada caso clínico, como as populações celulares envolvidas no controle das infecções, mas também no controle do crescimento de células tumorais a partir de nossos próprios tecidos, e também no disparar dos fenômenos autoimunes que superegoicamente figuram ataques de asma ou de artrite reumatóide.

A leitura do livro da Prof ${ }^{a}$ Deitos nos auxilia, assim, na retomada de um sentido originário da patologia: a partir de pathos, caminho, caminho descrito pelo corpo ao longo do percurso da doença, com suas mudanças celulares, teciduais, endócrinas e neurológicas. O sistema nervoso central/endócrino/ imunológico como eixo ao longo do qual se organiza a história da doença e não mais como a muralha que separaria a alma da materialidade supostamente decadente da carne.

Retomamos, assim, o sentido de um pensamento psicopatológico, como construção imaginativa que possibilita ao médico-terapeuta conversar com o corpo que sofre sobre o caminho que a doença vem marcando em seus vários âmbitos ao longo do tempo.

No livro IV da República, Platão diferencia o médico dos senhores, aquele que conversa com o paciente e a partir dele entende a história do mal que o acomete, do médico dos escravos, que trata a doença a partir do conhecimento genérico que a técnica separada da escuta clínica produz. A Prof ${ }^{a}$ Deitos, em seu livro, nos oferece uma via de retomada da nossa tradição, desde nossos antepassados xamânicos, passando pelo médico platônico, chegando aos dias onde a corporalidade, em seus aspectos celulares, humorais e teciduais, pode ser introduzida no diálogo alma a alma, corpo a corpo da prática terapêutica. Boa leitura, e boa sorte aos colegas! 